\title{
Role of Basal Media, Carbon Sources and Growth Regulators in Micropropagation of Two Valuable Medicinal Orchids of Bangladesh
}

\author{
Mohammed Mozammel Hoque ${ }^{1}$, Mohammad Al-Forkan ${ }^{2}$ \\ ${ }^{1}$ Department of Botany, University of Chittagong, Chittagong-4331, Bangladesh \\ ${ }^{2}$ Department of Genetic Engineering and Biotechnology, University of Chittagong, Chittagong-4331, Bangladesh
}

\begin{abstract}
An efficient, protocol for in vitro germination seeds of and micropropagation of two the valuable indigenous medicine Orchids namely; Bulbophyllum lilacinum Ridl. and Cymbidium aloifoloum $(L) S w$. were developed by enhanced shoot multiplication, nodal and leaf segments was designed. The medium type and various carbon sources, plant growth regulators markedly influenced in vitro propagation of $B$. lilacinum Ridl. and C. aloifoloum $(L) S w$. The in vitro protocorms production system was investigated on three $0.8 \%$ (w/v) agar solidified basal media namely; Phytomax Sigma Chemical Co. (PM), Modified Vacin and Went (MVW), Murashige and Shook,1962 (MS) medium with the synergistic combination of Auxin (IAA 1.0-2.0 $\mathrm{mgl}^{-1}$, IBA $2 \mathrm{mgl}^{-1}, \mathrm{NAA} 1.0-2.0 \mathrm{mgl} l^{-1}, 2,4-D$ 1.0mgl $\left.{ }^{-1}\right)$ , Cytokinins (BAP 0.5-2.0mgl $\mathrm{m}^{1}, \mathrm{Kn}$ 0.5-2mgl $\mathrm{I}^{-1}$ ) and $2 \%-3 \%$ sucrose which induced maximum number of shoots as well as beneficial shoot length. Sub culturing of nodal segments and leaf segments on similar medium enabled continuous production of healthy shoots with similar frequency. Rooting was highest $(2.96 \mathrm{~cm})$ on half strength MS medium containing $1.5 \%$ sucrose. The in vitro growing seedling were then transferred to outside natural environment through successive phases of acclimatization.
\end{abstract}

Keywords: Micropropagation, Protocorms, Bulbophyllum lilacinum, Cymbidium aloifoloum, Shoot multiplication and Growth regulators

\section{Introduction}

Orchids are economically important group of plants for their uses in floriculture, medicine and food industries. The diversity and population of orchid is decreasing due to human activities such as habitat destruction, degradation and fragmentation and over harvesting of selected orchids for commercial trade (Pant et al., 1999). Highly exploited species immediately require ex situ conservation by tissue culture method.

The application of tissue culture in multiplication of orchids dates back to second decade of twentieth century. Knudson (1922) became successful in germination of Cattleya, Laclia and Epidendrum seeds on agar medium containing sugar and concluded that mycohorizal fungus is not obligatory for orchid seed germination. After this discovery many other scientists became successful in in vitro germination of orchid seeds. At present a good number of improved media are used for in vitro germination of orchid seeds.

Micropropagation of orchids can also be done with the use of the aseptically grown seedling. The history of in vitro micropropagation of orchids through tissue culture dates back to 1960`s when Morel (1960) developed the technique of shoot apex culture in Cymbidium sp subsequently Ito (1960), Sagawa (1962), and Isreal (1963) demonstrated that in vitro germinated seedlings could be used in micropropagation. Later on different kinds of explants viz. shoot tips (Agrawal et al., 1992; Nagashima, 1999; Seeni and Lath, 2000), axilary buds (Wang,1988), root tips (Sanchez,1988), Leaf and nodal segments (Barua and Bhadra , 1999) rhizome tips (Takahashi, 1998; Sheelavantmath et al., 2000) were used for quick propagation of many commercially important orchid species
The plant growth regulators has an important role on growth and differentiation of cultured tissues and explants under in vitro conditions accordingly different kinds of PGRs of different nature are used in tissue culture media. The process of differentiation has been proved to be dependent of the ratio of auxins and cytokinins used in the culture media. In case of orchids tissue culture a good number of experiments have been carried out for understanding the role of different PGRs of auxin, and cytokinin group on the regeneration of different orchids from cultured tissues and organs.

Although the research in the area of orchid tissue culture has progressed tremendously in many countries, in Bangladesh only a very limited number of research study in this area have so for been carried out. The main constraints in the area of orchid micropropagation in Bangladesh area:

In view of the importance of rapid propagation of different indigenous orchids of Bangladesh, this research programme was undertaken with a view to develop a reproducible micropropagation technique for rapid multiplication of two medicinally important orchid species namely;, Bulbophyllum lilacinum, and Cymbidium aloifolium. The technique of in vitro seed germination, elongation, rooting and establishment in outside environment will be developed.

\section{Materials and Methods}

\section{Plant Material}

Selected two different indigenous orchids species namely; Bulbophyllum lilacinum Ridl. and Cymbidium aloifolium (L.) Sw, were selected for the study. The fruits of these species were collected from naturally grown plants of different region of Bangladesh, especially from Chittagong and Cox's Bazar, Collected fruits of were washed with 


\section{International Journal of Science and Research (IJSR) \\ ISSN (Online): 2319-7064 \\ Index Copernicus Value (2013): 6.14 | Impact Factor (2015): 6.391}

running tap water to remove dust particles and then washed with sterile distilled water 3-4 times. The capsule was surface sterilized by immersing it in the solution of $0.2 \%$ (w/v) $\mathrm{HgCl}_{2}$ for $10 \mathrm{~min}, 70 \%$ ethanol for $1 \mathrm{~min}$ and then washed for 2-3 times with double sterile distilled water.

In case of all species, the technique of in vitro seed germination and micropropagation were developed. Three different media namely, MS (Murashige and Skoog, 1962 with 3\% (w/v) sucrose, PM (Phytamaxe) with 2\% (w/v) sucrose and MVW (Modified after Vacin and Went 1949 ) with $2 \%(\mathrm{w} / \mathrm{v})$ sucrose were used for the aseptic culture of the seeds of Bulbophyllum lilacinum Ridl. and Cymbidium aloifolium (L.) Sw. For micropropagation MS and PM media were used as basal media with different combinations of different PGRs. The $\mathrm{P}^{\mathrm{H}}$ of all media was adjusted to 5.8 before autoclaving. Agar $(0.8 \% \mathrm{w} / \mathrm{v})$ was added as a gelling agent. Agar was dissolved by boiling the mixture and about $20 \mathrm{ml}$ media was dispensed into each culture tube $(150 \mathrm{x}$ $25 \mathrm{~mm}$ ) and autoclaved at $120{ }^{\circ} \mathrm{C}$ for $15 \mathrm{~min} / 15 \mathrm{lb}$. The cultures were maintained at $25 \pm 2{ }^{\circ} \mathrm{C}$ and 200-300 lux under $16 \mathrm{hrs}$ photoperiod.

\section{Subculture of seedlings}

When orchid seeds germinated and protocorms came out, these were taken out aseptically from the culture vessels and the masses of protocorms were sub cultured at a lower density on the same culture media for further growth. The sub-cultured materials were maintained in the same culture room under the same light and temperature conditions as used for germination. Further sub culturing was done at every 20-25 d interval when the masses of seedlings were further thinned.

\section{Subculture of tiny seedlings for rapid elongation}

Although in germination media the seedlings continued its growth but the growth rate was very slow. In order to induce rapid elongation, seedlings with 1-2 leaves were transferred to the elongation media. Here also regular subculturing was done at a lower density.

\section{Subculture of seedlings for induction of better root system}

In elongation media the seedlings produced weak root system. In order to induce strong and stout root system, the seedlings of $2-3 \mathrm{~cm}$ size were aseptically taken out of the culture vessels, separated from each other and sub-cultured on rooting media. Culture vessels were maintained in the same conditions.

Transplantation and establishment of in vitro grown seedlings outside of the culture room

In rooting medium the plantlets grew further and developed good root system, these were taken out of the cultural vessels and shifted out side the culture room following successive phases of acclimatization. For the purpose, the mouth of the culture vessels was kept open for one day in the culture room and then kept outside of the culture room for $6 \mathrm{~h}$. in the next day. Later on, those were kept outside of the culture room for $12 \mathrm{~h}$ in the third day. Finally the seedlings were taken out of the culture vessels and washed with running tap water for removal of agar attached to the roots. The seedlings were then transferred to small pots containing moisten coconut coir, coir dust and coal where those were grown for 20-30d. Finally the seedlings were transferred to wooden orchid pots filled up with moistened coconut coir, coal and small brick pieces. Here the seedlings eventually grew well.

\section{Culture of explants of in vitro grown seedlings for micropropagation}

Different explants viz. nodal and leaf segments of in vitro grown seedlings were used for micropropagation. For the purpose $0.8 \%$ (w/v) agar solidified MS, PM and MVW media supplemented with 2-3\% (w/v) sucrose and different concentrations and combinations of PGRs were used.

\section{Results and Discussion}

In vitro plant tissue culture is the most commercially successful aspect of plant biotechnology which has introduced an exciting new phase into plant propagation (Prakash et al.,1996) and orchid is the first horticultural plant multiplied by tissue culture methods on a commercial scale. Many researchers have reviewed the strategic approaches that may be applied in the development of reliable orchid regeneration system (Goh 1990; Sagawa 1990; Arditti and Ernst 1993; Prakash et al., 1996). In Bangladesh Ismat (1987); Hoque et al., (1994) and Das Gupta and Bhadra (1998) reported in vitro seed culture and propagation of Cymbidium. Das Gupta et al., (1998) reported on micropropagation of Dendrobium crepidatum but growth performance of survived plants and their flowering condition were not mentioned. Very recently a number of NGOs and private horticulture farms are trying to establish orchid industry in Bangladesh.

The present research study was under taken to develop protocols for rapid in vitro germination of important medicinal orchids species namely Bulbophyllum lilacinum Ridl. and Cymbidium aloifolium (L.) Sw. In the present investigation three different kinds of basal media, namely; MS, PM and MVW were used for in vitro germination of all selected orchid species. The results on germination indicate that PM was better than other two media for all these selected orchid species (Table 1). The germination of orchids seeds are medium dependent and interact with genotype. The emerged protocorms turned in to mini seedling and continued their growth in the germination media very slowly. For enhancement of growth rate, germinated seedlings were transferred to elongation media. Different types of PGRs (BAP, NAA, IBA, IAA, Pic. Kn and 2,4-D) and various combinations and concentration were used for the purpose (Table $2 \& 4$ ). Different hormone combination were found to be better for elongation of different species of Bulbophyllum lilacinum on $\mathrm{MS}+1.0$ $\mathrm{mgl}^{-1}$ IAA $+2.0 \mathrm{mgl}^{-1} \mathrm{BAP}+3 \%(\mathrm{w} / \mathrm{v})$ sucrose and Cymbidium aloifolium (L.) Sw. on $\mathrm{MS}+2.0 \mathrm{mgl}^{-1} \mathrm{NAA}+$ $3.0 \mathrm{mgl}^{-1} \mathrm{BAP}+1.0 \mathrm{mgl}^{-1} \mathrm{Kn}+3 \%$ (w/v) sucrose was better for elongation. It is relevant to mention here enhancement of the elongation of germinated seedling has been done with the supplementation of plant growth regulators in the medium in many orchid species (Barua and Bhadra,1999; Kusumoto, 1980; Kokubu et al., 1980; Geetha and shetty, 2000). 


\section{International Journal of Science and Research (IJSR) \\ ISSN (Online): 2319-7064 \\ Index Copernicus Value (2013): 6.14 | Impact Factor (2015): 6.391}

Although the seedlings developed roots in germination and elongation media, those were very weak. In order to induce strong and stout root system the seedling of two species namely; Bulbophyllum lilacinum Ridl. and Cymbidium aloifolium (L.) Sw. were transferred to two different rooting media while one Half MS $+1.5 \%$ (w/v) sucrose was most effective for development of strong root system. Another media MS + $0.5 \mathrm{mgl}^{-1}$ IAA $+3 \%(\mathrm{w} / \mathrm{v})$ sucrose was proved most efficient for induction of root system (Table 2). It is indicated that for induction of strong and stout root system either stress condition or auxin supplements promoted root growth. Similar finding was also noted in same orchid species by Gupta et al., (1998) and Bhadra et al., (2002).

Different explants such as nodal segment and leaf segment were used of in vitro culture of seedling on different media fortified with different combination and concentration of PGRs. The efficiency of the media was estimated in terms of number of multiple shoot buds produced from each explants. The overall results $\mathrm{MS}+2.0 \mathrm{mgl}^{-1} \mathrm{BAP}+1.5 \mathrm{mgl}^{-1} \mathrm{IAA}+$ $3 \%(\mathrm{w} / \mathrm{v})$ sucrose, $\mathrm{MS}+1.0 \mathrm{mgl}^{-1} \mathrm{IAA}+1.0 \mathrm{mgl}^{-1} \mathrm{Kn}+2.0$ $\mathrm{mgl}^{-1} \mathrm{BAP}+3 \%(\mathrm{w} / \mathrm{v})$ sucrose, $\mathrm{MS}+2.0 \mathrm{mgl}^{-1} \mathrm{BAP}+1.5$ $\mathrm{mgl}^{-1} \mathrm{IAA}+3 \%(\mathrm{w} / \mathrm{v})$ sucrose, $\mathrm{MS}+1.0 \mathrm{mgl}^{-1} \mathrm{NAA}+2.00$ $\mathrm{mgl}^{-1} \mathrm{BAP}+3 \%(\mathrm{w} / \mathrm{v})$ sucrose. In case of $C$. aloifolium multiple shoot buds obtained from both nodal segment and leaf segment when grow on MS $+1.0 \mathrm{mgl}^{-1} \mathrm{BAP}+2.0 \mathrm{mgl}^{-1}$ $\mathrm{IAA}+3 \%(\mathrm{w} / \mathrm{v})$ sucrose and $\mathrm{MS}+2.5 \mathrm{mgl}^{-1} \mathrm{NAA}+3 \%$ $(\mathrm{w} / \mathrm{v})$ sucrose(Table 4$)$. Similar result from other plant have been reported previously by many scientist (Bhadra et al.,2002; Bhadra and Hossain 2003).

In order to induce good root system the multiple shoot buds at a height of 1 to $2 \mathrm{~cm}$ were individually cultured on two different $0.8 \%(\mathrm{w} / \mathrm{v})$ agar solidified media namely; i) Half strength MS $+1.5 \%(\mathrm{w} / \mathrm{v})$ sucrose ii) Full strength MS + $0.5 \mathrm{mgl}^{-1} \mathrm{NAA}+3 \%(\mathrm{w} / \mathrm{v})$ sucrose. Half strength MS + $1.5 \%(\mathrm{w} / \mathrm{v})$ sucrose was more effective for rooting in case of all these species(Table 5). Similar results was noted by Bhadra et al., (2002); Bhadra et al., (2006). In vitro developed seedlings were finally transferred to outside and acclimatized in natural environment through sequential steps of acclimatization. The survival rate was $50 \%$ for $C$. aloifolium, $36 \%$ for $B$. lilacinum respectively. Similar finding was also noted in same orchid species by Geetha and shetty (2000), Seeni and Latha (2000) and Teixira da Silva et al., (2006). This protocol can be used in commercial and research laboratories for both rapid propagation and conservation of this medicinal orchid species.

\section{Conclusion}

The results indicated that the two species differed highly in terms of their response in tissue culture. The type of explants and the PGR supplements were found to be equally important for regeneration purpose.

Table 1: Percentage of in vitro germination of seeds of two orchid species on $0.8 \%$ (w/v) agar solidified MS, PM and MVW

\begin{tabular}{|c|c|c|c|c|}
\hline \multirow{3}{*}{ Name of the species } & $\begin{array}{c}\text { Name of } \\
\text { medium }\end{array}$ & $\begin{array}{c}\text { \% of seed } \\
\text { germination }\end{array}$ & $\begin{array}{c}\text { Time required for } \\
\text { germination (days) }\end{array}$ & Remarks \\
\cline { 2 - 5 } $\begin{array}{c}\text { Bulbophyllum } \\
\text { lilacinum }\end{array}$ & MS & - & - & Not germinated. \\
\cline { 2 - 5 } & PM & 80 & $30-35$ & Green seedlings were produced. \\
\cline { 2 - 5 } Cymbidium aloifolium & MVW & - & - & Green protocorms were produced \\
\cline { 2 - 5 } & MS & 90 & $30-35$ & Green seedlings were produced \\
\cline { 2 - 5 } & MVW & 90 & - & Not germinated. \\
\hline
\end{tabular}

\section{'-' Indicates no germination}

Table 2: Results * on the elongation of the germinated seedlings of Bulbophyllum lilacinum Ridl., Cymbidium aloifolium (L.) Sw. and on $0.8 \%$ (w/v) agar solidified media supplemented with different kinds of PGRs.

\begin{tabular}{|c|c|c|c|c|c|c|}
\hline \multirow[t]{2}{*}{ Culture media } & \multicolumn{2}{|c|}{$\begin{array}{l}\text { Seedlings length }(\mathrm{cm})^{* *} \\
\text { after } 60 \mathrm{~d} \text { of germination } \\
\text { (mean length) }\end{array}$} & \multicolumn{2}{|c|}{$\begin{array}{l}\text { Seedlings length }(\mathrm{cm}) \text { after } 30 \mathrm{~d} \\
\text { of culture on elongation } \\
\text { medium(mean length) }\end{array}$} & \multicolumn{2}{|c|}{$\begin{array}{c}\text { Seedlings length }(\mathrm{cm}) \text { increased } \\
\text { within } 30 \mathrm{~d} \text { of culture on } \\
\text { elongation medium }\end{array}$} \\
\hline & B lilacinum & C aloifolium & B lilacinum & C aloifolium & B lilacinum & C aloifolium \\
\hline $\mathrm{MS}+2.0 \mathrm{mgl}{ }^{\mathrm{I}} \mathrm{IAA}+3 \%(\mathrm{w} / \mathrm{v})$ sucrose & 1.20 & 1.40 & 2.30 & 2.70 & 1.10 & 1.30 \\
\hline $\begin{array}{c}\mathrm{MS}+1.0 \mathrm{mgl}^{-1} \mathrm{IAA}+2.0 \mathrm{mgl}^{-1} \mathrm{BAP}+ \\
3 \%(\mathrm{w} / \mathrm{v}) \text { sucrose }\end{array}$ & 1.30 & 1.50 & 3.10 & 3.40 & 1.80 & 1.90 \\
\hline $\mathrm{MS}+2.0 \mathrm{mgl}^{-1} \mathrm{BAP}+3 \%(\mathrm{w} / \mathrm{v})$ sucrose & 1.20 & 1.50 & 2.50 & 2.90 & 1.30 & 1.40 \\
\hline $\begin{array}{c}\mathrm{MS}+3.0 \mathrm{mgl}^{-1} \mathrm{BAP}+1.0 \mathrm{mgl}^{-1} \mathrm{NAA}+ \\
1.5 \mathrm{mgl}^{-1} \mathrm{Kn}+3 \%(\mathrm{w} / \mathrm{v}) \text { sucrose }\end{array}$ & 1.20 & 1.50 & 2.60 & 3.10 & 1.40 & 1.60 \\
\hline $\begin{array}{c}\mathrm{MS}+2.0 \mathrm{mgl}^{-1} \mathrm{NAA}+3.0 \mathrm{mgl}^{-1} \mathrm{BAP}+ \\
1.0 \mathrm{mgl}^{-1} \mathrm{Kn}+3 \%(\mathrm{w} / \mathrm{v}) \text { sucrose }\end{array}$ & 1.20 & 1.40 & 1.80 & 3.50 & 2.00 & 2.10 \\
\hline $\begin{array}{c}\mathrm{MS}+2.0 \mathrm{mgl}^{-1} \mathrm{NAA}+2.0 \mathrm{mgl}^{-1} \mathrm{BAP} \\
+3 \%(\mathrm{w} / \mathrm{v}) \text { sucrose }\end{array}$ & 1.40 & 1.40 & 2.70 & 2.70 & 1.30 & 1.30 \\
\hline $\begin{array}{c}\mathrm{MS}+1.0 \mathrm{mgl}^{-1} \mathrm{NAA}+0.5 \mathrm{mgl}^{-1} \mathrm{BAP}+ \\
3 \%(\mathrm{w} / \mathrm{v}) \text { sucrose }\end{array}$ & 1.2 & 1.40 & 2.6 & 3.10 & 1.4 & 1.70 \\
\hline $\begin{array}{c}\mathrm{MS}+2.0 \mathrm{mgl}^{-1} \mathrm{BAP}+0.1 \mathrm{mgl}^{-1} \mathrm{Pic}+3 \% \\
(\mathrm{w} / \mathrm{v}) \text { sucrose }\end{array}$ & 1.40 & 1.40 & 3.00 & 3.10 & 1.60 & 1.70 \\
\hline $\begin{array}{c}\mathrm{PM}+1.0 \mathrm{mgl}^{-1} 24-\mathrm{D}+2.0 \mathrm{mgl}^{-1} \mathrm{Kn}+ \\
3 \%(\mathrm{w} / \mathrm{v}) \text { sucrose }\end{array}$ & 1.5 & 1.50 & 2.6 & 3.40 & 1.10 & 1.90 \\
\hline $\mathrm{PM}+2.0 \mathrm{mgl}^{-1} \mathrm{IBA}+2 \%(\mathrm{w} / \mathrm{v})$ sucrose & 1.20 & 1.50 & 1.90 & 2.80 & 0.70 & 1.30 \\
\hline $\mathrm{PM}+2.0 \mathrm{mgl}^{-1} \mathrm{BAP}+2 \%(\mathrm{w} / \mathrm{v})$ sucrose & 1.20 & 1.50 & 2.20 & 2.70 & 1.00 & 1.20 \\
\hline
\end{tabular}

\section{Volume 5 Issue 6, June 2016 www.ijsr.net}




\section{International Journal of Science and Research (IJSR) \\ ISSN (Online): 2319-7064}

Index Copernicus Value (2013): 6.14 | Impact Factor (2015): 6.391

*Based on observations recorded from 50 seedlings taking 5 at random from each of 10 culture vessels.

** Only the length of shoot system.

Table 3: Results" on the induction of roots in Bulbophyllum lilacinum and Cymbidium aloifolium seedlings when grown on $0.8 \%(\mathrm{w} / \mathrm{v})$ agar solidified rooting media.

\begin{tabular}{|c|c|c|c|c|c|c|c|}
\hline & \multirow[t]{2}{*}{ Rooting media } & \multicolumn{2}{|c|}{$\begin{array}{l}\text { Seedling roots length }(\mathrm{cm}) \text { and } \\
\text { number before culture on } \\
\text { rooting medium (mean value) }\end{array}$} & \multicolumn{2}{|c|}{$\begin{array}{l}\text { Seedling roots length }(\mathrm{cm}) \text { and } \\
\text { number after } 30 \mathrm{~d} \text { of culture on } \\
\text { rooting medium (mean value) }\end{array}$} & \multicolumn{2}{|c|}{$\begin{array}{c}\text { Seedling roots length }(\mathrm{cm}) \text { and } \\
\text { number increased after } 30 \mathrm{~d} \text { of } \\
\text { culture on rooting medium (mean } \\
\text { value) }\end{array}$} \\
\hline & & $\begin{array}{l}\text { Length } \\
(\mathrm{cm})\end{array}$ & No.of roots / seedling & Length $(\mathrm{cm})$ & $\begin{array}{l}\text { No.of roots / } \\
\text { seedling }\end{array}$ & Length $(\mathrm{cm})$ & No.of roots / seedling \\
\hline \multirow[t]{2}{*}{$\begin{array}{c}\text { Bulbophyllum } \\
\text { lilacinum }\end{array}$} & $\begin{array}{c}\text { Half strength MS } \\
+1.5 \%(w / v) \\
\text { sucrose }\end{array}$ & 1.65 & 3.25 & 2.95 & 5.00 & 1.60 & 1.95 \\
\hline & $\begin{array}{c}\mathrm{MS}+0.5 \mathrm{mgl}^{-1} \\
\mathrm{IAA}+3 \%(\mathrm{w} / \mathrm{v}) \\
\text { sucrose }\end{array}$ & 1.52 & 3.65 & 2.60 & 5.05 & 1.28 & 1.60 \\
\hline \multirow[t]{2}{*}{$\begin{array}{l}\text { Cymbidium } \\
\text { aloifolium }\end{array}$} & $\begin{array}{c}\text { Half strength MS } \\
+1.5 \%(w / v) \\
\text { sucrose }\end{array}$ & 1.65 & 2.65 & 2.97 & 5.58 & 1.52 & 2.43 \\
\hline & $\begin{array}{l}\mathrm{MS}+0.5 \mathrm{mgl}^{-1} \\
\mathrm{IAA}+3 \%(\mathrm{w} / \mathrm{v}) \\
\text { sucrose }\end{array}$ & 1.52 & 2.43 & 2.62 & 4.56 & 1.30 & 2.33 \\
\hline
\end{tabular}

*Based on observations recorded from 50 seedlings taking 5 at random from each of 10 culture vessels.

Table 4: Results* ${ }^{* *}$ on the development of multiple shoot buds in nodal and leaf segments of Bulbophyllum lilacinum Ridl. and Cymbidium aloifolium (L.) Sw. on $0.8 \%$ (w/v) agar solidified media supplemented with different PGRs.

\begin{tabular}{|c|c|c|c|c|c|c|}
\hline \multirow[t]{2}{*}{ Culture media } & \multicolumn{2}{|c|}{$\begin{array}{l}\text { Name of the } \\
\text { explants }\end{array}$} & \multicolumn{2}{|c|}{$\begin{array}{l}\text { Days }(d) \text { required for } \\
\text { initiation and sprouting of } \\
\text { multiple shoot buds. }\end{array}$} & \multicolumn{2}{|c|}{$\begin{array}{l}\text { Number of shoot buds } \\
\text { sprouted (mean/explants) }\end{array}$} \\
\hline & B lilacinum & $C$ aloifolium & B lilacinum & C aloifolium & B lilacinum & $C$ aloifolium \\
\hline \multirow{2}{*}{$\begin{array}{c}\mathrm{MS}+2.0 \mathrm{mgl}^{-1} 2,4-\mathrm{D}+0.5 \mathrm{mgl}^{-1} \mathrm{Kn}+ \\
3 \%(\mathrm{w} / \mathrm{v}) \text { sucrose }\end{array}$} & NS & NS & $45-50$ & $35-40$ & 2.60 & 4.35 \\
\hline & $\mathrm{LS}$ & LS & - & - & - & - \\
\hline \multirow{2}{*}{$\begin{array}{c}\mathrm{MS}+2.0 \mathrm{mgl}^{-1} \mathrm{BAP}+1.5 \mathrm{mgl}^{-1} \mathrm{IAA}+ \\
\mathbf{3 \%}(\mathrm{w} / \mathrm{v}) \text { sucrose }\end{array}$} & NS & $\mathrm{NS}$ & $40-45$ & $35-40$ & 3.50 & 4.75 \\
\hline & LS & LS & - & - & - & - \\
\hline \multirow{2}{*}{$\begin{array}{c}\mathrm{MS}+2.0 \mathrm{mgl}^{-1} \mathrm{BAP}+2.0 \mathrm{mgl}^{-1} \mathrm{NAA}+ \\
3 \%(\mathrm{w} / \mathrm{v}) \text { sucrose }\end{array}$} & $\mathrm{NS}$ & NS & $40-45$ & $30-35$ & 2.80 & 4.40 \\
\hline & $\mathrm{LS}$ & LS & - & - & - & - \\
\hline \multirow[t]{2}{*}{$\mathrm{MS}+2.0 \mathrm{mgl}^{-1} \mathrm{NAA}+3 \%(\mathrm{w} / \mathrm{v})$ sucrose } & NS & NS & $40-45$ & $30-35$ & 2.50 & 4.40 \\
\hline & $\mathrm{LS}$ & LS & - & - & - & - \\
\hline \multirow{2}{*}{$\begin{array}{c}\mathrm{MS}+1.0 \mathrm{mgl}^{-1} \mathrm{NAA}+0.5 \mathrm{mgl}^{-1} \mathrm{BAP}+ \\
3 \%(\mathrm{w} / \mathrm{v}) \text { sucrose }\end{array}$} & $\mathrm{NS}$ & NS & $40-45$ & $35-40$ & 2.70 & 4.35 \\
\hline & $\mathrm{LS}$ & LS & - & - & - & - \\
\hline \multirow{2}{*}{$\begin{array}{c}\mathrm{PM}+1.0 \mathrm{mgl}^{-1} \mathrm{BAP}+0.5 \mathrm{mgl}^{-1} \mathrm{IAA}+ \\
2 \%(\mathrm{w} / \mathrm{v}) \text { sucrose }\end{array}$} & $\mathrm{NS}$ & $\mathrm{NS}$ & $40-45$ & $30-35$ & 2.70 & 4.50 \\
\hline & $\mathrm{LS}$ & LS & - & - & - & - \\
\hline \multirow{2}{*}{$\begin{array}{c}\mathrm{PM}+2.0 \mathrm{mgl}^{-1} \mathrm{BAP}+1.5 \mathrm{mgl}^{-1} \mathrm{IAA}+ \\
2 \%(\mathrm{w} / \mathrm{v}) \text { sucrose }\end{array}$} & NS & $\mathrm{NS}$ & $40-45$ & $40-45$ & 2.70 & 4.35 \\
\hline & LS & LS & - & - & - & - \\
\hline
\end{tabular}

*NS= Nodal Segment, LS= Leaf Segment, '-' Indicates no response

*** Based on observations recorded from 20 cultured segments.

Table 5: Results* on the development of roots of individual multiple shoot buds of Bulbophyllum lilacinum and Cymbidium aloifolium when grown on $0.8 \%$ (w/v) agar solidified rooting media

\begin{tabular}{|c|c|c|c|}
\hline $\begin{array}{c}\text { Name of the } \\
\text { species }\end{array}$ & Rooting media & $\begin{array}{l}\text { Roots length }(\mathrm{cm}) \text { after } 30 \mathrm{~d} \\
\text { of culture on rooting medium } \\
\text { (mean value) }\end{array}$ & $\begin{array}{l}\text { Mean number of } \\
\text { root/seedlings }\end{array}$ \\
\hline \multirow{2}{*}{$\begin{array}{l}\text { Bulbophyllum } \\
\text { lilacinum }\end{array}$} & $\mathrm{MS}+0.5 \mathrm{mgl}^{-1} \mathrm{IAA}+3 \%(\mathrm{w} / \mathrm{v})$ sucrose & 2.2 & 3.5 \\
\hline & Half strength MS + $1.5 \%(w / v)$ sucrose & 2.4 & 3.8 \\
\hline \multirow{2}{*}{$\begin{array}{l}\text { Cymbidium } \\
\text { aloifolium }\end{array}$} & $\mathrm{MS}+0.5 \mathrm{mgl}^{-1} \mathrm{IAA}+3 \%(\mathrm{w} / \mathrm{v})$ sucrose & 2.36 & 2.86 \\
\hline & Half strength MS + $1.5 \%(\mathrm{w} / \mathrm{v})$ sucrose & 2.96 & 3.8 \\
\hline
\end{tabular}

*Based on observations recorded from 25 seedlings taking 5 at random from each of 5 culture vessels.

\section{References}

[1] Agrawal, D. C., Morwal, G. C. AND Mascarenhas, A. F. 1992. In vitro propagation and slow growth storage of shoot cultures of Vanilla walkeriae Wight an endangered orchid. Lindleyana 7(2): 95-99.
[2] Arditti, J. and R. Ernst. 1993. Micropropagation of orchids. John Wiley and Sons. Inc., New York.

[3] Barua, A. K. and Bhadra, S. K. 1999. In vitro micropropagation of Cymbidium aloifolium (L.)Sw. and Spathoglottis plicata Bl. Plant Tissue Cult. (2): 133140.

Volume 5 Issue 6, June 2016 www.ijsr.net

Licensed Under Creative Commons Attribution CC BY 


\section{International Journal of Science and Research (IJSR) \\ ISSN (Online): 2319-7064 \\ Index Copernicus Value (2013): 6.14 | Impact Factor (2015): 6.391}

[4] Bhadra , S. K. 2004. Rapid multiplication of phalaenopsis through in vitro shoot and leaf culture. Annual Bangladesh Botanical Conf. held on Dec. 1416,2004 , at the Department of Botany, University of Rajshahi, Bangladesh . Abstract No 149, pp.78.

[5] Bhadra, S. K. and Hossain, M. M. 2003. In vitro germination and micropropagation of Geodorum densiflorum (Lam.) Schltr., an endangered orchid species. Plant Tissue Cult. . 13(2): 165-171.

[6] Bhadra, S. K., Barua, A. K., Bhattacharjee, B. and Hossain, M. M. 2002. In vitro germination and micropropagation of Dendrobium aphyllum G. E. C. Fischer. Bangladesh J. Genet and Biotechnol. 3(1\&2): 47-50

[7] Bhadra, S. K., Hossain, M. M. and Nandy, P. 2006. In vitro mass propagation of Phalaenopsis consu-cervi (BREDA) PAR and Reichb. F. through direct organogenesis. The Chitt. Unvi. J. of Bio. Sci. 1 (1) : 43-47.

[8] Das, A. and Ghosal, K. K. 1989. In vitro germination behavior of some orchid seeds developed in plants of west Bengal. Indian Agriculturist. 33(2): 103-109.

[9] Das Gupta, P. and S. K. Bhadra 1998. In vitro Production of Seedling in Cymbidium aloifolium (L). Sw. Plant Tissue Cult. 8(2): 177-182.

[10] Das Gupta, P., M. Al-Forkan and S. K. Bhadra. 1998. Micropropagation through Seeds and Shoot Segments in Dendrobium crepidatum Lindl. Plant Tissue Cult. 8(1): 1-10

[11] Geetha, S. and Shetty, S. A. 2000. In vitro propagation of Vanilla planifolia, a tropical orchid. Current Science 79(6): 886-889.

[12] Goh, C. J. 1990. Orchids-monopodials. In: Handbook of Plant Cell Culture. Ornamental species. Ammirato, P.V., D. A. EVANS, W. R. Sharp and Y. P. S. Bajaj (eds.). Mc Graw-Hill, New York. pp.5: 598-637.

[13] Gupta, P. D. and Bhadra, S. K. 1998. In vitro production of seedlings in Cymbidium aloifolium L.SW. Plant Tiss Cult. 8(2): 177-182.

[14] Hoque, M. I., Roy, A. R. , Sarker, R. H. and Hoque, M. M. 1994. Micropropagation of Cymbidium bicolor through in vitro culture. Plant Tiss Cult. 4(1) : 45-51

[15] Islam, N. 1987. An attempt towards micropropagation of some orchids of Bangladesh. M Sc. Thesis, Department of Botany, Univ. Dhaka, Dhaka.

[16] Isreal, H. W. 1963. Production of Dendrobium seedlings by aseptic culture of excised ovules. American Orchid Soc. Bull. 32: 441-443.

[17] Ito, I. 1960. Culture of orchid seedlings by way of completing the growth of ovaries of cut flowers. Japan Orchid Soc. Bull. 6: 4-7.

[18] Knudson, L. 1922. Non-symbiotic germination of orchid seeds. Bot. Gaz. 73:1-15.

[19] Kokubu, T., Kaieda, Y., Higashi, Y., Kitano, T. and Kukamizu, K. 198. Organogenesis in sterile culture of oriental Cymbidium karan. Men. Fac. Agric. Kagoshima Univ. 15(25): 53-64.

[20] Kusumoto, M. 1980. Effects of CM agar and sucrose concentrations and media $\mathrm{pH}$ on the proliferation of Cymbidium PLBs cultured in vitro J. Japanese Soc. Hortic. Sci. 48(4): 503-509.

[21] Morel, G. 1960. Producing virus free Cymbidium. American Orchid Soc. Bull. 29: 459-497.
[22] Murashige, T. and Skoog, F. 1962. A revised medium for rapid growth and bioassay with tobacco tissue culture. Physiol. Plantarum. 15: 473-497.

[23] Nagashima, T. 1999. A study on culture media for shoot apices and roots in Habenaria radiata Sprengle. Conservation and Propagation of Endangered Wild Orchids of the World. Proc. of the International Orchid wave in Simanami.

[24] Pant B .R. P. Chqudhary, and L. R. Shakya. 1999. Introducing modern biotechnology for the conservation and propagation of Nepalese Orchid. In Proveeding of the international orchid wave in simanami 99. An international orchid conference on "Conservation and propagation of Endangered Wild Orchid of the World", pp 74-80. Simanami.

[25] Prakash, L., C. L. Lee, C. S. Loh and C. J. Goh. 1996. In vitro propagation of commercial orchids: an assessment of current methodologies and development of a novel approach- thin cross-section culture. In: Plant Tissue Culture, Islam A.S. (Ed.). pp. 42-49. Oxford and IBS Publishing Co. Pvt. New Delhi.

[26] Roy, S. and Biswas, A. K. 2001. In vitro regeneration and hardening of plantlets through seed culture in Spathogottis plicata (Blume). Fourth International Plant Tissue Culture Conf. held on Nov. 1-3. In Dhaka, Bangladesh, pp-1.

[27] Sagawa, Y. 1962. Embryo culture in Phalaenopsis. American Orchid Soc. Bull. 31: 819-821.

[28] Sagawa, Y. 1990. Orchids, other consideration. In: Handbook of Plant Cell Culture. Vol. 5. Ornamental species. Ammirato, P. V., D. A. Evans, W. R. Sharp and Y. P. S. Bajaj (eds.). pp. 638-653. McGraw- Hill, New York.

[29] Seeni, S. and Latha, P. G. 2000. In vitro multiplication and ecorehabilitation of the endangered Blue Vanda. Plant Cell Tiss and Org Cult. 61(1): 1-8.

[30] Takahashi, C. T. and Kondo, K. 1999. Induction of adventitious shoots, rhizome-derived protocorm like bodies and abnormal shoot tip aggregations from rhizome segments of Pogonia japonica. Lindleyana 13(4): 284-291.

[31] Teixeira da silva, J. A. , Singh, N. and Tanaka, M. 2006. Proming biotic factors for optimal protocorm like body and callus induction in hybrid Cymbidium (Orchidaceae), and assessment of cytogenic stability in regenerated plantlets. Plant Cell, Tissue and Organ Culture ; 84: 135-144. DOI 10.1007/s11240-005-9003-0

[32] Wang, X. 1988. Tissue culture of Cymbidium, plant and flower induction in vitro. Lindleyana 3(4): 184-189. 